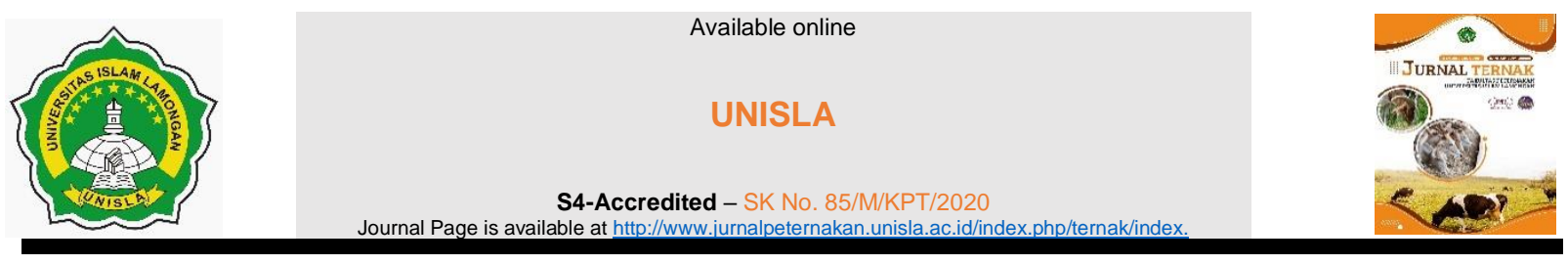

\title{
Potential of Small-Scale Business Development and Sociocultural of Beef Cattle Farm at Pamekasan Regency: Case Study at Madura Island
}

\author{
Asri Nurul Hudaa, Aulia Puspita Anugera Yektib, Poespitasari Hazanah Ndaruc, Jaisy \\ Aghniarahim Putritamarad, Danung Nur Adlie, and Zulfaini Shamadf \\ a,b,c,d,e,f Faculty of Animal Science, University of Brawijaya, Malang, East Java, Indonesia \\ email: "nurulasri@ub.ac.id
}

\begin{tabular}{l}
\hline A R T I C L E I N F O \\
\hline Article history: \\
Received 14 December 2021 \\
Revised 30 December 2021 \\
Accepted 13 January 2021 \\
Available online 14 January \\
2021 \\
\hline
\end{tabular}

Keywords:

Adoption

Beef Cattle

Madura Cattle

Pamekasan

Socio-culture

IEEE style in citing this article:

A.N. Huda, A.P.A. Yekti,

P.H. Ndaru, J.A.

Putritamara, D.N. Adli, and

Z. Shamad, " Potential of

small-scale business

development and

sociocultural of Beef cattle at

Pamekasan Regency: Study

case at Madura Island ,"

Jurnal Ternak Universitas

Islam Lamongan, vol. 12,

no. 1, pp. $1-5,2021$

\section{A B S T R A C T}

Most of beef cattle farmers in Indonesia are dominated by small-scale farmer with ownership of three heads per household, however the existence of small-scale farmer were apparently support development into the animal sectore as whole. The interview was conducted with the total respondent on 30 beef cattle farmers at Larangan Dalam and Panaguan Village, Larangan Sub-District, Pamekasan Regency. The majority of the respondents' age range was 46-50 years old, with male breeders dominating, approximately $76.67 \%$, with the most educational qualifications being elementary school, approximately $46.67 \%$. The age and education level significantly affected the adoption rate of new technology. The objectives of raising livestock were fattening, breeding, and savings. In summary, the socio-culture was acted as important support in small-scale business development. The correlation between each socio-culture with new adaptation to help increasing productivity in the future.

\section{Introduction}

Madura Island is one of the Potential Island that belongs to East Java Province, Indonesia. The diversity in Madura Island is started with the domestic cattle that namely "Madura cattle." The Madura cattle belongs to domestic cattle with species Bos Taurus or Bos indicus, which both of them are derivated from aurochs (Bos primigenius In line, thus cattle contributed to small- scale economic farming-system in Madura Island [1], Madura Island's total population supports 5.8\% of the total national population of beef cattle at 190.635 heads (Pamekasan Regency) [4]. The records of Madura cattle has been poorly documented and managed. The small-scale cattle in Indonesia were rearing and raising at around less than three heads on one farm [3]. Madura beef cattle may want to grow on low-fine fodder and a excessive fertile. A deer-like temperament makes them maximum appropriate for in depth village- 
based management for plowing rice paddy fields, however their hoofs are too gentle for draught on paved roads. Meat from young animals has a popularity for being noticeably tender [9].

Moreover, the business on the farm of beef cattle consists of breeding and fattening. The fattening system is popular among traditional farmer since the cash flow is more profitable rather than breeding. Furthermore, the breeding business has more potential high income if the farmer-focused on nutrient management programs [7]. The management programs are supported by socio-culture aspect [11]. The factors that influence the socio-culture are socio-culture, social networks, and cultural assets. Several types of some breeds may elevate farmers' social status. Subsequently, financial capital is important regarding social class. The farmers' networking may define the knowledge about breeding and farming, so that, the output exposure is important in determining farmers' opinions. The farmers' networking may also determine the decision making related to cattle keeping and the farmers' sociocultural status. Based on the description above, this research analyzed from the perspective of socio-culture potential in the small-scale business development and sociocultural of beef cattle at Pamekasan Regency.

\section{Material and Method}

The researcher interviewed 30 beef cattle farmers at Larangan Dalam and Panaguan Village, Larangan Sub-District, Pamekasan Regency. The method was convenience sampling as primary data taken from a strategic site. The total respondent were at 30 farmers, these samples already followed minimum descriptive method research from [14] stated on the descriptive method research at least 10\%$20 \%$ of the population, while for the research requiread sample of 30 respondents. Compared the statement from [15] required a sample at range 15-30 were needed to taken a sample in field. Following with backup data was apparently taken from published articles from google scholar, Pub Med, or each articles [4] and reports from institutions. Moreover a semi-structured interview was conducted due to interviews with predefined domains of interest; the questions and conversations were directed in a certain direction [2]. There was some lack of language which is hard to understand. The condition were take action by using some native interpreter to translate the native which belongs to Maduranese. It mean, the unclear word were processed to understanding and interpreted precisely for actually of this research [5]. The data were analyzed descriptively, and qualitatively continued compared with related theory [12].

\section{Results and Discussion}

The beef cattle farmers located in the Larangan Dalam and Panaguan Village, Larangan SubDistrict, Pamekasan Regency were curvilinear support and local government extension (UPT Disnakvet). Supporting agencies were as follows: rearing, feeding management, economic culture. The innovation in the modeling house and feed technologies was introduced to farmers; later, the socioculture made the time of adaptation longer [8]. Table 1 showed that the respondent's characteristic was at several factors, i.e., age, sex, and education qualification. The majority of the age was at range 46-50 years old the $76.67 \%$ (men) of farmers were had elementary school degree $(46.67 \%)$. Reported from [10] stated that a majority of farmers (57\%) aged between 51-60 years old, while only $43 \%$ were aged less than 51 years. Mostly $40 \%$ of farmers already went to high school; only $7 \%$ of farmers were graduated from university in the Pamekasan Regency, East Java, Indonesia. [10] reported that there was a strong relationship between level of education and income improvement of farmers.

The finding of the education level variable did not have an individual and significant effect on the profit of smallscale beef cattle business in the beef cattle farmer in Yogjakarta. Following the opinion, this condition an educational factors did not significantly influence the profit level. [11] reported that age and education level were affected by the accuracy of new adoption technology. Meanwhile, if the technology introduction were lower on one side, it will be affected to feed consumption and productivity [8]. The adaption and farmers group di one place had essential factors for increasing the well-being of the life farmers include the opportunity to collaborate with the outside institution [8]. The farmer's group established since there was no such organization on site.

In term of social characteristics, the people of Larangan sub-district have strong characteristics in the livestock business that can be used as important capital in developing their business, of course this characteristic was not necessarily shared by farmers in other regions. This was indicated by the effort of 
farmers to provide alternative forages when there was a scarcity of forages during dry season by utilizing the local potential. They provided legume and non-legume plant leaves and also tree plant leaves such as mango and jackfruit leaves for used as forages and gave it to the cattle. Rice straw became the last choice, when the green forages cannot be found. This indicates they attempt to provide the best feed for their livestock business.

Table 1. Respondency characteristics

\begin{tabular}{ccc}
\hline Characteristic & Frequency & Percentage (\%) \\
\hline Age (Years old) & 1 & 3.33 \\
$\mathbf{3 1 - 3 5}$ & 2 & 6.67 \\
$\mathbf{3 6 - 4 0}$ & 5 & 16.67 \\
$\mathbf{4 1 - 4 5}$ & 9 & 30.00 \\
$\mathbf{4 6 - 5 0}$ & 6 & 20.00 \\
$\mathbf{5 1 - 5 5}$ & 4 & 13.33 \\
$\mathbf{5 6 - 6 0}$ & 1 & 3.33 \\
$\mathbf{6 1 - 6 5}$ & 2 & 6.67 \\
$\mathbf{6 6 - 7 0}$ & 30 & 100 \\
\hline Total & & \\
\hline Sex & 23 & 76.67 \\
Men & 7 & 23.33 \\
Women & 30 & 100 \\
\hline Total & & \\
Education levels & 14 & 46.67 \\
Elementary school school & 4 & 13.33 \\
Secondary school school & 6 & 20.00 \\
High-School & 1 & 3.33 \\
Higher education (University) & 5 & 16.67 \\
Unknown & 30 & 100 \\
\hline Total & 8 & \\
\hline Purposes & 0 & 26.67 \\
Fattening & 10 & 0 \\
Breeding & 30 & 33.33 \\
Combination & & 100 \\
Saving & &
\end{tabular}

Mostly the purposes of becoming farmers were as saving. In urgent time the cattle were sold based on the need. Normally, the number of cattle usually less than three heads among farmers. The cattle were belong to assets of farmers by gaining from social-networks cultural. In this networking the farmers' lives are organized around Madura cattle; maintaining Madura cattle is the center of most people's lives in Pamekasan. This focuses on Madura cattle is good financial capital farmers can generate, as mentioned earlier.

The unique cultural management of the beef cattle farmer on Madura was using a sharing system. The model was not only one owner, but the investor also had this cattle within the rent system. The total from 30 respondences $45.23 \%$ beef cattle status was "loan as described in Table 2 . The agreement was as follows: 1) Farmers (Secondary farmers) were loan the heifer from other farmers (first farmers), in the future, the heifer will produce offspring, the second farmer will own the offspring. Afterwards, the second-generation will be given back. 2) The secondary farmers who loan the heifer will be sharing the cost of selling weaned cattle. 3) $50 \%$ profit will be shared by both first and secondary farmers if the fattening cattle happen. Furthermore, farmers prefer to sign agreements based on contracts because they were considered more profitable and transparent, but unfortunately the farmers have not recorded a detailed cost analysis. The current situation beef cattle owned by farmers can be seen on the table 2 . 
Table 2. The beef cattle status owned by farmers

\begin{tabular}{lccc}
\hline \multicolumn{1}{c}{ Status } & Permanent & Loan & Total \\
\hline Total (Heads) & 23 & 19 & 42 \\
Percentage (\%) & 54,76 & 45,23 & 100 \\
\hline
\end{tabular}

The culture of maintaining beef cattle was not a tradition they held on to in this sub-district. The farmers choose to secure their livelihoods and financial capital. Throughout this sceme, social capital increased as a result of the adoption of new technologies. Based on the Table 2, the communities had the potential to increase their small-scale business, but consistency is needed according to support in the future (table 2). The side job role must be replaced as the primary role. On Java, crossbreeding has been completed since a long time, while it became lately added on Madura. Most districts without crossbreeds have little understanding approximately crossbreeds and they have negative perceptions about it. Meanwhile, in other districts that have been familiar with crossbred cattle for a longer period, farmers consider crossed cattle to be more profitable and have higher productivity than native Madura cattle. The result of the improved behaviour is the increase of productivity, income, and livelihood.

External factors that negatively affect the behavior of farmers need to get the attention of the government because the current extension workers are hardly trusted by breeders [17]. Public perception, ease acces to cattle production facilities and marketing of produce cannot improve the farmer behaviour [18], therefore, extension must be based on something innovative, and marketoriented, so that it can provide benefits to farmers to developed constantly [19].

Social and cultural aspects in Pamekasan Regency were able to work together to support sustainable beef cattle farms especially in these three study areas. Farmers used the following bases: financial security (saving), income, providing manure, utilization of crop by-products, raising the social status of their owner, cultural events, draught purposes, and hobbies, as guidelines for running a beef cattle business [20]. Most farmers mentioned 'saving' as the most important motivation. Farmers consider saving in selling cattle to meet unexpected or large expenditures, such as sending children to school, paying hospital bills for a family member, financing a wedding party, or a pilgrimage to Mekka. Farmers consider income as the cash they regularly receive from progeny's annual sale [12]. The appearance of the cow and the weaning period greatly affected the growth of the offspring [16].

\section{Conclusions}

In summary, the socio-culture was acted as crucial support in the small-scale business development. The correlation between each socio-culture with new adaptation was a help to increase productivity in the future. In return, farmers choose the cattle in support regarding financial addition and capital gaining, whether in future lack of natural income.

\section{Acknowledgment}

The author would like to say gratitude to the local farmer of Larangan Sub-District, Pamekasan Regency Madura. The research funding was supported by the University of Brawijaya through a "Beginners' Researcher Grant" scheme with contract number 436.58/UN10. C10/PN/2020.

\section{References}

[1] F. Achmad, and J.H. Mulyo. 2019. "Factors Affecting Profit Analysis of Small-Scale Beef Cattle Farmers in the Special Region of Yogyakarta, Indonesia," American-Eurasian J. of Sust. Agr., vol. 13, no. 2, pp. 1-12, 2019, doi:10.22587/aejsa.2019.13.2.1

[2] M. Agroniso, "Doing ethnographic and observational research," Los Angeles, C: Sage Publications, 2007.

[3] R.M. Aprilia, Marjuki dan Hartutik, "Evaluasi kandungan nutrient konsentrat yang diberikan pada sapi perah di Kabupaten Malang," J. Nutr. T. Trop., vol. 1, no. 1, 54-59, 2018, doi.org/10.21776/ub.jnt.2018.001.01.7 
[4] Badan Pusat Statistik (BPS), 2019, Beef cattle population 2017-2019. Jakarta;BPS RI. https://www.bps.go.id/indicator/24/469/1/populasi-sapi-potong-menurut-provinsi.html [Accessed 08 November 2020].

[5] J. Bujra, "Lost is translation? The use of interpreters in fieldwork," In: Vandana Desai and Robert B. Potter (eds) Doing Development Research. London: Sage Publications, pp. 172-179, 2006.

[6] S. A. Ejembi, and H.O. Obekpa. "Effects of Socio-Cultural Factors on Effective Agricultural Training Programs for Farmers by the Benue State Agricultural Development Authority in Zone C,". J. of Asian Rur. Stud., vol. 1, no. 1, 60-69, 2017, doi:10.17170/kobra-20190709595

[7] A. Khoiri, N. Badriyah, dan D. W. Aspriati, "Analisis Kelayakan Finansial Usaha Pembibitan Sapi Pedaging Di Desa Pucuk Kecamatan Pucuk Kabupaten Lamongan,", J. Ternak, vol. 7, no. 1, pp. 1-6, 2016

[8] E. Mutiah, A. Abdullah, dan S. Nurlaelah, "Identifikasi Peranan Kelompok sebagai wahana Kerja Sama Peternak Sapi Potong pada Peternakan Rakyat," Agripet, vol. 18, no. 1, pp. 57-62, 2018, doi.org/10.17969/agripet.v18i1.10971

[9] K. Mohamad, M. Olsson, H. T. van Tol, S. Mikko, B.H. Vlamings, G. Andersson, H.R. Martinez, B. Purwantara, R.W. Paling, B. Colenbrander, J.A. Lenstra., "On the origin of Indonesian cattle," PLoS One, vol.4, no.5, e5490, 2009

[10] H.D. Utami, A. Yakin, and A.P. Seruni, "Determinants Affecting on Smallholder Madura Cattle Farming at Pamekasan Regency, East Java, Indonesia.," EEES, vol 119, no. 1, pp. 012063, 2018, doi :10.1088/1755-1315/119/1/012063

[11] K.E. Ravhuhali, V. Mlambo, T.S. Beyene, U. Luvhengo, and L. Palamuleni, "Socio-cultural perceptions of communal farmers towards rangeland degradation in selected localities of South Africa,".Range Mgmt \& Agrof., vol. 41, no. 1, 147-155, 2020

[12] Sugiyono, "Metode Penelitian Kuantitaif dan Kualitatif," R \& B, Bandung: Alfabeta, 2011.

[13] N. Widyas, S. Prastowo, R. Haryanto, T. Nugroho, and T.S.M. Widi, "Madura cattle stratification as a signature of traditional selection and diverse production systems,". In IOP Conf. Ser. Earth and Env. Sci., vol. 387, no. 1, Pp. 012120, 2019, doi:10.1088/1755-1315/387/1/012120

[14] W. R. Borg, Meredith D.G., and Joyce P.G. "Education Research," New York: Pearson Education, Inc, 2007.

[15] L.R. Gay, Geoffrey E.M, and Peter A. 2009. "Educational Research, Competencies for Analysis and Application," New Jersey: Pearson Education, Inc, 2009.

[16] R. Priyanto, J.R Riwukore, A. Yani, B.P. Purwanto, L. Abdullah, A.M. Fuah, and F. Habaora, "Analysis of Dynamic System Toward Governor Policy of Nusa Tenggara Timur about Quota of Beef Cattle Export (Case Study in Plantation Agroecosystem of Timor Island)". Ann. Res. \& Rev. in Biol., pp. 32-41, 2020, doi: 10.9734/ARRB/2020/v35i530223

[17] F. Habaora, A.M. Fuah, L. Abdullah, R. Priyanto, A. Yani, and B.P. Purwanto, "Attitude Analysis of Bali Cattle Farmers toward Credit Programs Based on Agroecosystems in Timor Island,". Int. J. Innovative Sci. Res. Technol, vol. 4, 769-776, 2019, https://doi.org/10.9734/arrb/2020/v35i530223

[18] N. Hilmiati, B. Budiwiranto, and E. van de Fliert. 2017. Gender, ethnicity and engagement: Uptake strategies for smallholder cattle farming innovation in West Nusa Tenggara, Indonesia. Rur. Ext. and Innov. Systems J., vol. 13, no. 2, pp. 61, 2017

[19] O. Mapiye, , O.C. Chikwanha, G. Makombe, K. Dzama, and C. Mapiye, "Livelihood, Food and Nutrition Security in Southern Africa: What Role Do Indigenous Cattle Genetic Resources Play? Diversity, vol. 12, no. 2, pp. 74, 2020, https://doi.org/10.3390/d12020074.

[20] T. S. M.Widi, H. Udo, K. Oldenbroek, I. G. S. Budisatria, E. Baliarti, and A. V der Zijpp. "Designing genetic impact assessment for crossbreeding with exotic beef breeds in mixed farming systems," Outlook on Agr., 0030727020915206, 2020 